\title{
Effects of disturbances generated by different management strategies at Nothofagus antarctica forest on beetles assemblage of Chubut, Argentina
}

\begin{abstract}
Nothofagus antarctica is a species of the Andino-patagónico forest with a wide distribution from the north of Neuquén to Tierra del Fuego. $N$. antartica forests are intensely affected nowadays by human activities such as grazing, firewood, conversion into pastures and the replacement by conifer plantations. These activities produce changes in $N$. antarctica forest, mainly by the alteration of its original structure affecting the performance of the ecosystem as a whole, resulting in the loss of biodiversity. In this sense, little is known about the effects of these disturbances on Coleoptera communities that contribute to faunal biodiversity and play key roles in the ecosystem's dynamics. The response of beetle assemblages to disturbances and the dependence of that response on habitat type were analyzed in this study. Beetles were collected by fluid interception and sticky traps, and by foliage sections shaking; and plant species richness and vegetation cover were measured.

A total of 354 beetles representing 17 families were captured, with 25 species identified and 8 not identified. Multivariate analysis revealed that disturbances affected the composition of the beetle assemblage similarity. According to this analysis, the composition of beetle was different among sampling sites FWL, B25 and PR; while it was similar among sites $\mathrm{B} 15$, FWL and PC sampling sites. We found a significant relationship between abundance and structural vegetation characteristics, and this was a positive relationship with shrub stratum cover in PR and B25 sampling sites. Finally, we found an increase in the abundance of beetles with vegetation richness in B25 and PR samplings sites, and these increases had a positive relationship to shrub stratum richness in both sites. These results suggest that in Patagonia, the disturbances on Nothofagus antarctica forests can have a substantial effect on beetle communities, and the consequences of these perturbations depend on habitat type. The pre-disturbed conditions of each habitat type and the distribution of species among the different habitats and how these species use the habitats determined their ability to deal with pos-disturbance conditions. Disturbances produce simplification and homogenization of habitat types and this could reflected by beetle diversity, so a good knowledge of the beetle usage of habitat and how the habitat utilization may change along a regional gradient is necessary to understand the effect of disturbance on native beetle assemblages.
\end{abstract}

Volume 2 Issue 5 - 2018

\begin{abstract}
Gönc RL, Casaux R
Consejo Nacional de Investigaciones Científicas y Tecnológicas, Argentina
\end{abstract}

Correspondence: Gönc RL, Consejo Nacional de Investigaciones Científicas y Tecnológicas, Ciudad Autónoma de Buenos Aires, CABA, Argentina, Email goncromina@gmail.com

Received: August 21, 2018 | Published: September 17, 2018

Keywords: coleoptera, Nothofagus antarctica, disturbance, Patagonia Argentina

\section{Introduction}

Biodiversity continues to decline in the face of increasing anthropogenic pressures, such as habitat loss and fragmentation, biological invasions, exploitation, pollution and introduction of exotic species. ${ }^{1}$ Understanding the factors behind biodiversity loss is one of the most urgent tasks faced by scientists at present. In Patagonia, the consequences resulting from human activity on the forest, mainly Nothofagus, ${ }^{2}$ and in particular of $N$. antarctica forest, are the loss of diversity, degradation, fragmentation of habitat, overexploitation of species, introduction of exotic species, ${ }^{3,4}$ and the like. These losses could be due to changes in the forest structure, microclimatic conditions or nutrient cycles. ${ }^{5,6}$

The habitat type (distinguished by complexity level) is one of the most important factors as it usually modulates the effect of other agents on natural communities. ${ }^{7,8}$ In some ecosystems habitat may become less complex after disturbance because of the reduction of vegetation cover, ${ }^{9}$ so, in consequence, the disturbance may have different effects on communities depending on the type of habitat, and the response of communities will vary depending on the capacity of their species to deal with the post - disturbance conditions. ${ }^{9}$ Species adapted to more complex habitats, for example habitats with more vegetation stratums, which can mean more environmental niches and more foraging opportunities for the species, will be more severely affected than species that prefer less complex habitats (e.g. habitats with less vegetation stratums). ${ }^{10}$

Beetles are tightly linked to ecosystem functioning: they can attain large biomass and represent a great proportion of the total species diversity of an ecosystem. ${ }^{11}$ These taxa have been shown to be sensitive to habitat disturbance, like burning, ${ }^{12}$ and have also shown to be useful bioindicators for environment monitoring and assessment, with their high diversity and sensitive to environmental conditions, providing a view of ecological change. , $^{6,13,14}$

Few studies have documented changes in post-disturbance insects and arthropods in the Andean forest, but these studies have addressed principally the effects of fire on beetle assemblages. ${ }^{10,15,16}$ Improving our knowledge of beetle assemblages in the context of forest disturbances and management is necessary for effective arthropod conservation. ${ }^{17}$ In this study we analyzed the effect of disturbances on beetle (Coleoptera) assemblages in $N$. antarctica forests. The specific aims of the study were: (1) to compare beetle abundance and 
richness across different forest disturbance sites, (2) to describe the relationship between beetle diversity and vegetation structure in these habitats and (3) to determine whether beetle abundance, richness and vegetation variables could explain the response after disturbance.

\section{Materials and methods}

\section{Sampling sites}

For the selection of Nothofagus antarctica forest sectors affected by different disturbances we used satellite images shared by the staff of the INTA EEA San Carlos de Bariloche (Río Negro Province) and EEA Esquel (Chubut Province) (Hansen et al., unpublished information) and field information obtained in this study. The selected study sites belong to the same basin (Futaleufú) and the ranges of altitude (between 600 and 840 meters above sea level) and distance among sites (17km between the farthest points) were as narrow as possible. In addition, the original structure of $N$. antarctica forest in all sampling sites were similar (patches with $N$. antarctica individuals between 4 and 8 meters in height).

The disturbances on $N$. antarctica forest considered in this study were: 1) firewood extraction by patches (FWP), 2) firewood extraction by landscaped (FWL), 3) conversion of forest into pasture (PC), 4) fires occurring 15 years ago (B15), and 5) fires occurring 25 years ago (B25). As a control, we also considered pristine forests (PR). Two replicates were considered for each disturbance type (10 sampling sites) and for the pristine forest (2 sampling sites), and the minimum distance between replicates was 1,500 meters.

\section{Sampling design}

\section{Beetle sampling}

The samples were obtained in two consecutive seasons. Mobile adult individuals of the order Coleoptera were collected every three months (every sampling was carried out during the central period of each season) from July 2008 to June 2010. The sampling was carried out in dry and calm days. Fluid interception traps, with an area of $1 \mathrm{~m}^{2}$, were used to collect beetles at the leaf litter level. Beetles were collected in five trays of $400 \mathrm{~cm}^{3}$ containing a solution of water and antifreeze to prevent the escape of the specimens and to slow their decomposition according to the methodology described in News (1998) and Southwood (1989). At each site we selected one specimen of the three dominant species belonging to the shrub or arboreal stratum which were used to sample beetles associated to the foliage (the same species sampled throughout the study). The foliage was sprayed with insecticide and shaken for thirty seconds, and the beetles that fell were collected in a deep trough. ${ }^{18,19}$ These samples were integrated in a single sample. Finally, beetles associated with tree trunks were collected with three "Sticky" traps. These traps consisted of clear adhesive plastic of $90 \mathrm{~cm}^{2}$, and each one was placed with a different cardinal orientation. This approach was repeated at all the selected trees. The samples were integrated into a single. Sticky and fluid interception traps remained in the sampling sites over a period of 24 hours. Then, beetles were extracted from the traps and preserved in ethanol $70^{\circ}$.

At the laboratory the beetles were determined to species or morpho-species, through the observation of the morphological characters normally used for the determination of each group, with the help of guides and taxonomic keys ${ }^{20-25}$ and specialized taxonomists. The material was deposited at the laboratory of forest health of the
Asentamiento Universitario San Martin de los Andes, Universidad Nacional del Comahue (AUSMA).

\section{Vegetation sampling}

The information was also obtained from July 2008 to June 2010 . We randomly selected three sampling points at each sampling site where the following information was obtained in a radius of five meters from such points:

i. Full cover by strata according to the scale described by BraunBlanquet $^{26}$ and Mueller-Dombois \& Ellenberg ${ }^{27}$ (herbaceous strata below $0.6 \mathrm{~m}$., shrub strata between 0.6 and $3 \mathrm{~m}$, and arboreal strata above $3 \mathrm{~m})$. When the main strata were composed by substratums, these were also considered (Annex I).

ii. Species composition: we identified the species represented in each stratum with the help of the information in Dimitri \& Orfila ${ }^{28}$ and Zuloaga et al. ${ }^{29}$ Due to morphological similarities among species, Poa ligularis and P. pratensis, Senecio filaginoides and S. neaei, and Bromus setifolius and B. stamineus, were grouped by gender. Species were also classified according to their origin, either native or exotic (Annex I).

Annex I Vegetation species composition and stratum cover (mean \pm S.D.) of Nothofagus antarctica forest at each sampling site (FWP, firewood extraction by patches; FWL, firewood extraction by landscaped; PC, conversion of forest into pasture; BI 5 , fires occurred I 5 years ago; B25, fires occurred 25 years ago; PR, Pristine forests)

\begin{tabular}{|c|c|c|c|}
\hline Sampling site & Stratum & $\mathbf{n}$ & Mean \pm S.D. \\
\hline \multirow{3}{*}{ BI5 } & Herbaceous & 8 & $28.38 \pm 19.04$ \\
\hline & Shrub & 17 & $24.71 \pm 19.33$ \\
\hline & Arboreal & 2 & $49 \pm 15.56$ \\
\hline \multirow{3}{*}{ B25 } & Herbaceous & 20 & $12.95 \pm 15.29$ \\
\hline & Shrub & 14 & $15.36 \pm 18.39$ \\
\hline & Arboreal & 12 & 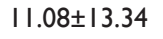 \\
\hline \multirow{3}{*}{ PR } & Herbaceous & 15 & $6.87 \pm 10.05$ \\
\hline & Shrub & 21 & $12.95 \pm 17.49$ \\
\hline & Arboreal & 4 & $7 \pm 2.16$ \\
\hline \multirow{3}{*}{ FWL } & Herbaceous & 18 & $19.5 \pm 18.2$ \\
\hline & Shrub & 13 & $9.69 \pm 14.07$ \\
\hline & Arboreal & 6 & $24.33 \pm 12.8$ \\
\hline \multirow{3}{*}{ FWP } & Herbaceous & 16 & $27.88 \pm 38.66$ \\
\hline & Shrub & 14 & $20.7 I \pm 28.79$ \\
\hline & Arboreal & 4 & $6.5 \pm 4.51$ \\
\hline \multirow{2}{*}{ PC } & Herbaceous & 8 & $7.25 \pm 7.5$ \\
\hline & Shrub & 3 & $2.67 \pm 1.53$ \\
\hline
\end{tabular}

\section{Data analyses}

We measured the effect of forest disturbances on the abundance of Coleoptera and vegetation stratum cover using General Linear Model (GLM) ANOVA, with sampling sites (PR, PC, FWL, FWP, B15 and B25) as factors, and sampling season (8) as repeated measures. ${ }^{16}$ Tukey tests were used for posterior comparisons. ${ }^{30}$ Abundances were transformed to meet ANOVA assumptions: $\mathrm{x}^{\prime}=\log (\mathrm{x}+1)$. Given that 
the estimation of species richness can be influenced by differences in sample size, expected richness was calculated and compared using sample-based rarefaction curves. ${ }^{31}$ Rarefaction eliminates variation in species richness due to differences in sample size by re-sampling a pool of $\mathrm{n}$ individuals repeatedly at random. ${ }^{31}$ Rarefaction was used to estimate beetle richness in each sampling site.

Analysis of similarity (ANOSIM) with Bray-Curtis similarity index was used to determine if there were significant differences in beetle assemblages among the sampling sites (B15, B25, FWL, FWP, PC and PR). ${ }^{15,32}$ ANOSIM is a non-parametric permutation procedure applied to rank similarity matrices underlying sample ordinations. The test is based on comparing distances among groups with distances within groups. ANOSIM produces a R-statistic that is an absolute measure of distance among groups. A large positive $\mathrm{R}$ (up to 1) means high dissimilarity among groups. Significance is computed by permutation of group membership. To display the relationship between different sampling sites we used non-metric multidimensional scaling (NMDS) with the Bray-Curtis similarity coefficient. ${ }^{15,33}$ The NMDS algorithm attempts to place data points in a coordinate system such that ranked distances are preserved. This method is well suited for non-normal data and does not assume linear relationships among variables.
ANOVA, rarefaction curves, ANOSIM and NMDS were performed with PAST $1.34 .{ }^{34}$

To describe the relationship between beetles and vegetation cover, correlations were performed (Pearson's coefficient) between beetles abundance and vegetation structure parameters (richness and cover stratum). This analysis was made with Infostat Profesional v.2014. ${ }^{35}$

\section{Results}

A total of 2743 beetles belonging to 17 families were represented in the samples; $89.13 \%$ of them were assigned to 25 species and the remaining was assigned to eight unidentified species (Table 1). The most abundant families were Curculionidae $(26.24 \%$ of the total of the individuals sampled) and Staphylinidae (17.68\%), followed by Scarabaeideae (12.43\%) (Table 1). The most abundant species were Entiminae sp. (Shoenherr, 1823), Anthonomini sp. (Thomson, 1859) and Aleocharinae sp. (Fleming, 1821). The highest abundances were registered at FWP and FWL (95 and 70 individuals respectively), while the lowest abundance was registered at PC and PR (48 and 30 individuals respectively) (Table 1). The highest and the lowest richness were registered at FWL (23 species) and at PR (13 species) respectively (Table 1).

Table I Beetle abundance and richness (mean \pm S.D.) in each sampling sites (FWP, firewood extraction by patches; FWL, firewood extraction by landscaped; PC, conversion of forest into pasture; BI5, fires occurred 15 years ago; B25, fires occurred 25 years ago; PR, Pristine forests)

\begin{tabular}{|c|c|c|c|c|c|}
\hline Family & Species & $\begin{array}{l}\text { Sampling } \\
\text { site }\end{array}$ & $\begin{array}{l}\text { Total } \\
\text { Abundance }\end{array}$ & Mean士S.D. & Richness \pm S.D. \\
\hline Anthicidae & sp. 8 & PC & 1 & 1 & 0 \\
\hline \multirow[t]{2}{*}{ Brupestidae } & \multirow[t]{2}{*}{ sp. I } & $\mathrm{BI} 5$ & 1 & 1 & 0 \\
\hline & & $\mathrm{FWL}$ & 2 & 1 & 0.24 \\
\hline \multirow[t]{5}{*}{ Cantharidae } & \multirow[t]{3}{*}{ Chauliognathus sp. } & FWP & 3 & 1 & 0.24 \\
\hline & & PR & 2 & 2 & 0.19 \\
\hline & & BI5 & 6 & $2 \pm 1$ & $0 \pm 0.14$ \\
\hline & \multirow[t]{2}{*}{ Cnemalobus araucanus } & $\mathrm{FWL}$ & I & 1 & 0.14 \\
\hline & & FWP & 2 & 2 & 0 \\
\hline \multirow[t]{6}{*}{ Carabidae } & \multirow{2}{*}{ Mimodromius chilensis } & FWP & I & 1 & 0.14 \\
\hline & & $\mathrm{PC}$ & I & I & 0.14 \\
\hline & \multirow{2}{*}{ Mimodromius nigrotestaceus } & FWP & 3 & 3 & 0.14 \\
\hline & & PC & 1 & 1 & 0.14 \\
\hline & \multirow[t]{2}{*}{ Calydon submetallicum } & $\mathrm{BI} 5$ & 2 & 1 & 0.14 \\
\hline & & $\mathrm{BI} 5$ & 1 & 1 & 0.14 \\
\hline \multirow[t]{5}{*}{ Cerambicidae } & \multirow{3}{*}{ Eryphus laetus } & FWL & 7 & 2 & 0 \\
\hline & & FWP & 2 & I & 0.14 \\
\hline & & PC & 2 & $3.5 \pm 3.54$ & $0.2 \mathrm{I} \pm 0.5 \mathrm{I}$ \\
\hline & \multirow{2}{*}{ Jansonius aeneus } & B25 & 1 & I & 0.19 \\
\hline & & PR & 3 & I & 0.19 \\
\hline \multirow{4}{*}{ Chrysomelidae } & \multirow{2}{*}{ Kuschelina decorata } & B25 & 8 & $2.67 \pm 2.08$ & $0.03 \pm 0.2$ \\
\hline & & PR & I & I & 0.19 \\
\hline & \multirow{2}{*}{ Mylassa crasicollis } & B25 & 10 & $3.33 \pm 2.53$ & $0.03 \pm 0.24$ \\
\hline & & $\mathrm{FWL}$ & 6 & $1.2 \pm 0.45$ & $0.17 \pm 0.04$ \\
\hline
\end{tabular}


Table Continued

\begin{tabular}{|c|c|c|c|c|c|}
\hline Family & Species & $\begin{array}{l}\text { Sampling } \\
\text { site }\end{array}$ & $\begin{array}{l}\text { Total } \\
\text { Abundance }\end{array}$ & Mean士S.D. & Richness \pm S.D. \\
\hline \multirow{11}{*}{ Coccinelidae } & \multirow{5}{*}{ Adalia angulifera } & BI5 & 7 & $2.33 \pm 0.58$ & $0.06 \pm 0.06$ \\
\hline & & B25 & 1 & 1 & 0.19 \\
\hline & & FWL & 2 & 1 & 0.19 \\
\hline & & FWP & 1 & 1 & 0.19 \\
\hline & & PC & I & 1 & 0 \\
\hline & \multirow{3}{*}{ Adalia deficiens } & BI5 & 1 & 1 & 0.19 \\
\hline & & B25 & 1 & 1 & 0.19 \\
\hline & & FWL & 3 & $1.5 \pm 0.7 \mid$ & $0.14 \pm 0.07$ \\
\hline & \multirow{3}{*}{ Coccinella chilena } & BI5 & 1 & 1 & 0.19 \\
\hline & & FWL & 2 & 1 & 0.19 \\
\hline & & PC & 1 & 1 & 0.19 \\
\hline \multirow{21}{*}{ Curculionidae } & \multirow{4}{*}{ Alastropolus sp. } & BI5 & 2 & 1 & 0.21 \\
\hline & & B25 & 2 & 2 & 0.14 \\
\hline & & $\mathrm{FWL}$ & 2 & 2 & 0.14 \\
\hline & & PC & 2 & 2 & 0.14 \\
\hline & \multirow{6}{*}{ Anthonomini sp. } & BI5 & 9 & $2.25 \pm 1.5$ & $0.13 \pm 0.11$ \\
\hline & & B25 & 1 & 1 & 0.21 \\
\hline & & FWL & 3 & 1 & 0.21 \\
\hline & & FWP & 13 & $2.6 \pm 2.3$ & $0.1 \pm 0.16$ \\
\hline & & PC & 6 & 3 & 0.07 \\
\hline & & PR & 1 & 1 & 0.21 \\
\hline & \multirow{5}{*}{ Cryptorrhynchini sp. } & BI5 & 1 & 1 & 0.21 \\
\hline & & B25 & 1 & 1 & 0.21 \\
\hline & & FWL & 4 & $2 \pm 1.4 \mid$ & $0.14 \pm 0.1$ \\
\hline & & PC & 6 & 6 & 0.14 \\
\hline & & PR & 1 & 1 & 0.21 \\
\hline & \multirow{6}{*}{ Entiminae sp. } & BI5 & 5 & $2.5 \pm 0.7 \mathrm{I}$ & $0.11 \pm 0.05$ \\
\hline & & B25 & 4 & 1 & 0.21 \\
\hline & & FWL & 10 & $2 \pm 1.22$ & $0.14 \pm 0.09$ \\
\hline & & FWP & 9 & $1.29 \pm 0.49$ & $0.19 \pm 0.03$ \\
\hline & & PC & 1 & 1 & 0.21 \\
\hline & & PR & 3 & 3 & 0.07 \\
\hline Elateridae & sp. 3 & FWL & 2 & 2 & 0.29 \\
\hline \multirow[t]{3}{*}{ Lucanidae } & \multirow[t]{3}{*}{ sp. 2} & FWL & 1 & 1 & 0 \\
\hline & & B25 & 14 & $3.5 \pm 2.38$ & $0.7 I \pm 0.68$ \\
\hline & & FWL & 2 & 1 & 0 \\
\hline \multirow[t]{3}{*}{ Melyridae } & \multirow[t]{3}{*}{ sp. 4} & FWP & 4 & $2 \pm|.4|$ & $0.29 \pm 0.4$ \\
\hline & & PC & 1 & 1 & 0 \\
\hline & & PR & 3 & 3 & 0.57 \\
\hline \multirow{2}{*}{ Nitulidae } & \multirow{2}{*}{ sp. 5} & FWL & 1 & 1 & 0 \\
\hline & & FWP & 2 & I & 0 \\
\hline
\end{tabular}




\begin{tabular}{|c|c|c|c|c|c|}
\hline Family & Species & $\begin{array}{l}\text { Sampling } \\
\text { site }\end{array}$ & $\begin{array}{l}\text { Total } \\
\text { Abundance }\end{array}$ & Mean $\pm S . D$. & Richness \pm S.D. \\
\hline \multirow{2}{*}{ Salpingidae } & \multirow{2}{*}{ sp. 6} & BI5 & 4 & 3 & 0.57 \\
\hline & & B25 & I & I & 0 \\
\hline \multirow{13}{*}{ Scarabaeidae } & \multirow[t]{2}{*}{ Aphodius sp. } & FWP & 4 & 4 & 0.06 \\
\hline & & BI5 & 1 & 1 & 0.23 \\
\hline & \multirow[t]{2}{*}{ Brachysternus sp. } & FWL & 5 & $1.25 \pm 0.5$ & $0.21 \pm 0.03$ \\
\hline & & PC & 2 & 2 & 0.17 \\
\hline & Oryctomorphus sp. & FWL & 2 & 1 & 0.23 \\
\hline & \multirow{2}{*}{ Phytolasma sp. } & BI5 & I & 1 & 0.23 \\
\hline & & FWP & 1 & 1 & 0.23 \\
\hline & \multirow{6}{*}{ Sericoides sp. } & BI5 & 2 & 2 & 0.17 \\
\hline & & B25 & I & 1 & 0.23 \\
\hline & & FWL & 7 & $1.75 \pm 0.96$ & $0.19 \pm 0.05$ \\
\hline & & FWP & I & 1 & 0.23 \\
\hline & & PC & 12 & $4 \pm 3$ & $0.06 \pm 0.17$ \\
\hline & & PR & 3 & 3 & 0.11 \\
\hline \multirow[t]{8}{*}{ Scolytidae } & \multirow[t]{3}{*}{ sp. 7} & PR & I & 1 & 0 \\
\hline & & BI5 & 2 & 1 & 0.19 \\
\hline & & B25 & 7 & $2.33 \pm 2.31$ & $0.06 \pm 0.22$ \\
\hline & \multirow[t]{5}{*}{ Aleocharinae sp. } & FWL & 7 & $3.5 \pm 0.7 \mid$ & $0.05 \pm 0.07$ \\
\hline & & FWP & 31 & $7.75 \pm 11.53$ & $0.45 \pm 1.1$ \\
\hline & & PR & 4 & $2 \pm|.4|$ & $0.1 \pm 0.13$ \\
\hline & & $\mathrm{B} \mid 5$ & I & 1 & 0.19 \\
\hline & & B25 & 2 & 1 & 0.19 \\
\hline \multirow{10}{*}{ Staphylinidae } & \multirow{4}{*}{ Leptoglossula sp. } & $\mathrm{FWL}$ & 2 & 2 & 0.1 \\
\hline & & FWP & 7 & $3.5 \pm 2.12$ & $0.05 \pm 0.2$ \\
\hline & & PC & 2 & 2 & 0.1 \\
\hline & & PR & 3 & $|.5 \pm 0.7|$ & $0.14 \pm 0.07$ \\
\hline & & B25 & 11 & $3.67 \pm 3.79$ & $0.06 \pm 0.36$ \\
\hline & & FWL & 2 & 2 & 0.1 \\
\hline & Thinodromus sp. & FWP & 3 & 1 & 0.19 \\
\hline & & PC & 2 & 2 & 0.1 \\
\hline & & PR & 4 & 2 & 0.1 \\
\hline & & FWL & 1 & 1 & 0 \\
\hline \multirow[t]{2}{*}{ Tenebrionidae } & Nyctelia rotundipennis & FWP & 6 & $1.5 \pm 0.58$ & $0.14 \pm 0.17$ \\
\hline & & PC & 1 & 1 & 0 \\
\hline
\end{tabular}

The abundance of beetles was similar among sampling sites (ANOVA, $\mathrm{F}_{5 ; 142}=1.01 ; \mathrm{p}=0.4167$ ) and sampling seasons (ANOVA, $\left.\mathrm{F}_{7 \cdot 142}=1.33 ; \mathrm{p}=0.2398\right)$. The interaction term were not significant $\left(\mathrm{F}_{31: 142}=1.49 ; \mathrm{p}=0.0628\right)$. The expected richness of beetles were similar among sampling sites $\left(\mathrm{F}_{5.142}=1.35 ; \mathrm{p}=0.2454\right)$ and sampling season $\left(\mathrm{F}_{7 ; 142}=0.78 ; \mathrm{p}=0.6056\right)$. The interaction among factors were not significant $\left(\mathrm{F}_{31 ; 142}=0.60 ; \mathrm{p}=0.9501\right)$.

Coleoptera expected richness at FWL was $23 \%$ higher than at the remaining sites (Figure 1c), and was followed in importance by FWP and PC (Figure 1d) (Figure1f). The expected richness at B25, B15, and PR were similar (Figure 1b-1e) and lower than at the remaining sites.

ANOSIM and NMDS ordination revealed that forest disturbances affected the composition of beetle assemblage (Table 2) (Figure 2). Beetle assemblage composition was similar among B15, FWL and PC sampling sites (Table 2) (Figure 2). In contrast, beetle assemblage was different among FWL, B25 and PR sampling sites (Table 2) (Figure 2). 


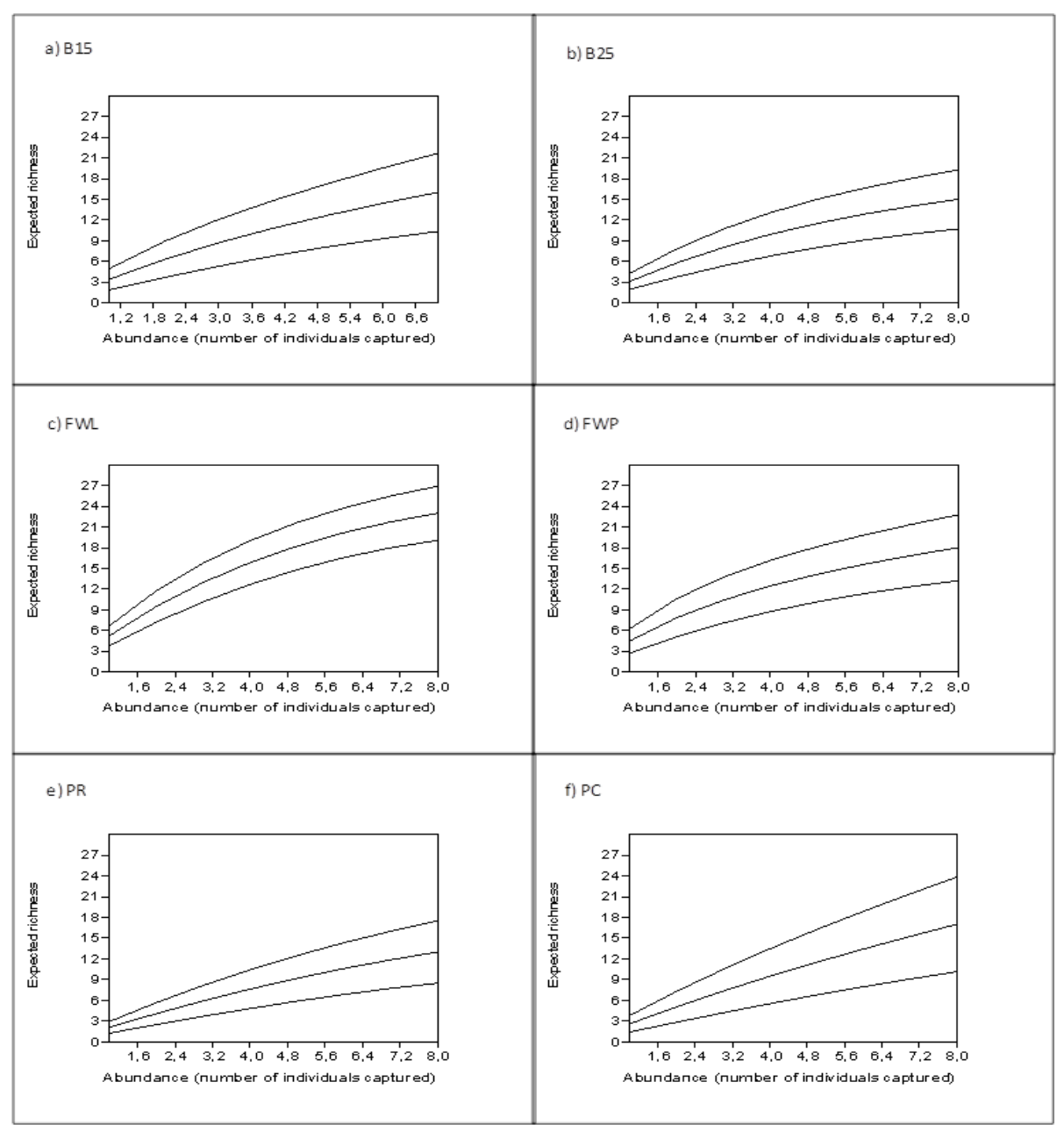

Figure I Sample-based rarefaction curves rescaled to individuals used to compare expected species richness of beetles (Coleoptera) in sampling sites. Data are means \pm SD after randomization.

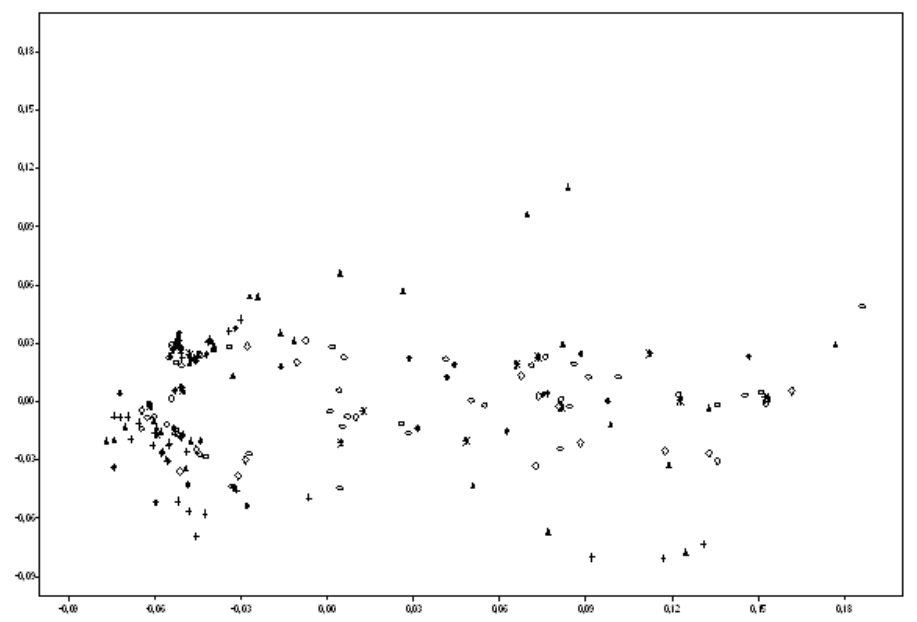

Figure 2 Non-metric multidimensional scaling ordination of beetle's assemblage based on sampling sites.

Sampling sites: FWP, PC, X BI5, B25, FWL, *PR. For ANOSIM results, see Table 2.

Citation: Gönc RL, Casaux R. Effects of disturbances generated by different management strategies at Nothofagus antarctica forest on beetles assemblage of Chubut, Argentina. Biodiversity Int J. 20 I8;2(5):4I5-423. DOI: I0.15406/bij.20I8.02.00094 
Table 2 Analysis of similarity (ANOSIM) for beetle assemblages between sampling sites (FWP, firewood extraction by patches; FWL, firewood extraction by landscaped; PC, conversion of forest into pasture; BI5, fires occurred 15 years ago; B25, fires occurred 25 years ago; PR, Pristine forests)

\begin{tabular}{lll}
\hline Comparison sampling sites & R & p values \\
\hline BI5 vs. B25 & 0.01 & 0.2126 \\
BI5 vs. FWL & -0.02 & 0.8837 \\
BI5 vs. FWP & -0.02 & 0.8097 \\
BI5 vs. PR & -0.03 & 0.753 \\
BI5 vs. PC & 0.12 & 0.0414 \\
B25 vs. FWL & 0.001 & 0.39 \\
B25 vs. FWP & -0.01 & 0.5914 \\
B25 vs. PR & 0.002 & 0.4133 \\
B25 vs. PC & 0.09 & 0.088 \\
FWL vs. FWP & -0.04 & 0.8334 \\
FWL vs. PR & -0.02 & 0.6926 \\
FWL vs. PC & 0.11 & 0.0346 \\
FWP vs. PR & -0.02 & 0.6412 \\
FWP vs. PC & 0.08 & 0.1377 \\
PR vs. PC & 0.06 & 0.8958 \\
\hline
\end{tabular}

Statistically significant relationships were observed between beetle abundance and vegetation richness and cover. Beetle abundance increased with vegetation cover at $\mathrm{B} 25(\mathrm{r}=0.35 ; \mathrm{p}=0.0174)$ and PR $(\mathrm{r}=0.50 ; \mathrm{p}=0.0011)$. These positive relationships were also observed when the beetle abundance was compared with the shrub stratum cover at both sites $(\mathrm{r}=0.54 ; \mathrm{p}=0.0462$ at $\mathrm{B} 25 ; \mathrm{r}=0.67 ; \mathrm{p}=0.0008$ at $\mathrm{PR})$ (Figure 3). Beetle abundance also increased with vegetation richness at $\mathrm{B} 25(\mathrm{r}=0.35 ; \mathrm{p}=0.0174)$ and $\mathrm{PR}(\mathrm{r}=0.45 ; \mathrm{p}=0.0039)$ and with shrub stratum richness at $\mathrm{B} 25(\mathrm{r}=0.54 ; \mathrm{p}=0.0462)$ and $\mathrm{PR}(\mathrm{r}=0.61$; $\mathrm{p}=0.0030$ ) (Figure 4).

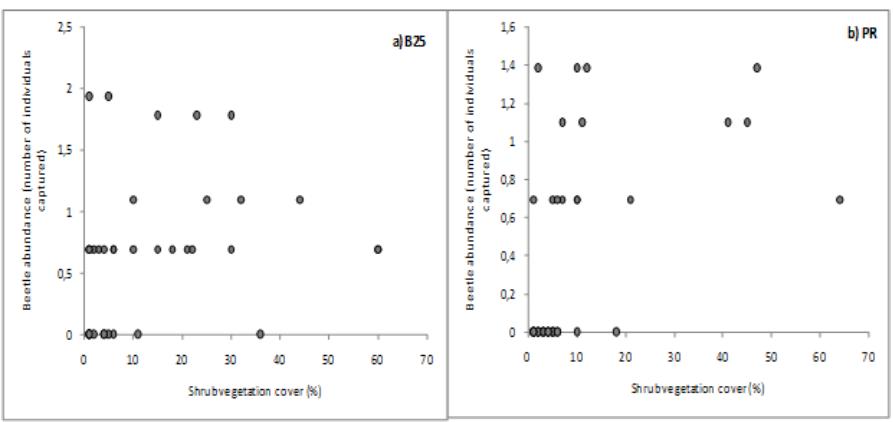

Figure 3 Correlation between beetle species abundance and shrub vegetation cover in B25 and PR sampling sites. Only significant correlations are shown.

\section{Discussion}

Beetle assemblages were affected by disturbances on $N$. antarctica forest by different mechanisms. Although not found significant differences in the abundance of individuals among the sampling sites, may be due to the number of species is relatively low compared with previous studies of bettle species. ${ }^{15}$ However the expected richness and abundance showed the highest value in FWL and FWP among other sampling sites. Sackmann \& Farji-Brener ${ }^{15}$ proposed that the reduction in abundance of some families was compensated for by an increase in another; thus, overall Coleoptera abundance was similar between disturbance and in not disturbance plots, and some species could have been benefited from recent post-disturbance conditions and immigrated to perturb other area; furthermore, some could survive. ${ }^{16}$

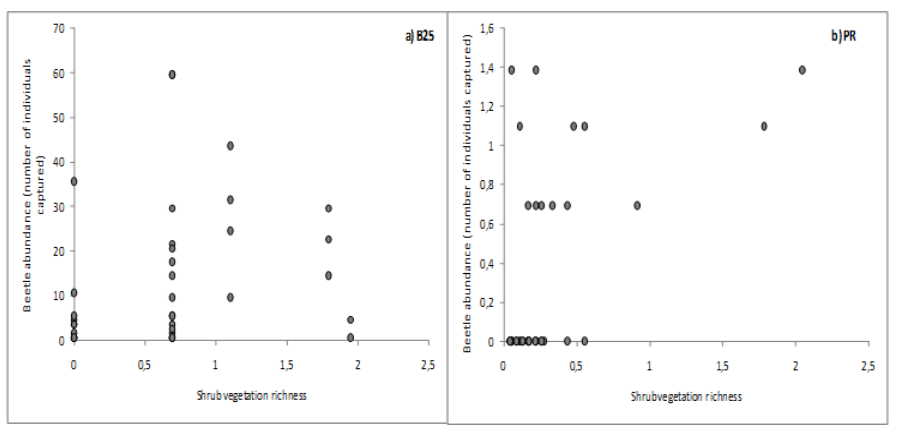

Figure 4 Correlation between beetle species abundance and shrub vegetation richness in B25 and PR sampling sites. Only significant correlations are shown.

Differences in beetle species composition were found among sampling sites rather than among sampling season. Beetle species composition was similar in B15, FWL and PC, but it was different among FWL, B25 and PR sampling sites. This pattern of beetle succession could occurred at the same time as the vegetation recovery patterns, although vegetation changed among habitats, so that species beetle composition could be influenced by recolonization and recovery rate of communities of plants after disturbances. ${ }^{36}$

Vegetation cover represents aspects of the productivity of habitats that may have a significant positive impact on beetle abundance. ${ }^{37}$ The intrinsic heterogeneity of the habitat and spatial segregation of taxa within the habitat (use of different microhabitats), and the consequent simplification post disturbance affect the distribution and frequently of beeltes families. ${ }^{38,15}$ In this study, shrub cover is the most important predictor of beetle abundance. This association suggests that shrubs may offer foraging and oviposition sites for beetles, thus promoting a local increase in abundance. Some authors ${ }^{39,40}$ suggest that the positive association of canopy cover with beetle abundance could explain the high sensitivity of beetles to habitat disturbances in vegetation structure caused by humans. Canopy closure has shown to favor distinct, smallscale microhabitats at the soil surface, generating a diverse mosaic of environmental conditions that affect the abundance and distribution of species. ${ }^{41}$ An increase in shrub cover probably provides more food resources and shelter against microclimatic variation, which may in turn increase beetle abundance in sampling sites. In this study, the effect of stratum cover on beetle abundance varied among sampling sites. Shrub cover affected beetle abundance positively in B25 and PR, and did not affect the abundance of beetles in the remaining sampling sites. Similar results were found by Ruggiero et al., ${ }^{42}$ and Sasal et al., ${ }^{16}$ in Nothofagus forests, and they suggest that in some environments the shrubs may act as "keystone" structures, which beetles may actively choose, as they provide important resources of food, thermal refuges, and protection against predators. ${ }^{43,44}$ Bess et al., ${ }^{36}$ showed that certain Coleoptera species preferred open, bare ground habitat and that they increased as well after disturbances like fire. On the other hand, we did not find an association among beetle abundance and arboreal and herbaceous stratums. In contrast, Ruggiero et $\mathrm{al} .{ }^{42}$ found a negative association between these variables. So we cannot explain this interesting pattern. For instance, forest beetles are closely associated with variation in understory plant cover in the Northern Hemisphere. ${ }^{37}$ 
Pre-disturbance conditions of each habitat type determined different post-disturbance communities' response. Beetle assemblages pattern was influenced by habitats structure rather than season conditions. Disturbance produced simplifications and homogenization of habitat types, and this was reflected by beetle diversity. Our results support the idea that the consequences of disturbance on beetle assemblages depend on habitat type (e.g. differences in structural complexity of vegetation), so it is possible that beetle assemblages recover as vegetation does. ${ }^{36}$ These findings suggest that beetles could provide effective indicators of disturbance, but further studies would be necessary to understand the factors underlying in the relationship among beetle abundance vegetation structures. In particular the distribution of species among the different sampling sites and the way that those species use the habitats (e.g. preference for shrub stratums) will determine their ability to deal with post - disturbance conditions. This implies that a good knowledge of the beetle usage of habitat and how the habitat utilization may change along a regional gradient is necessary to understand the effect of disturbance on native beetle assemblages.

\section{Acknowledgments}

We deeply thank M. Archangelsky and S. Tiranti who helped with species determination, and J. Di Rienzo for assistance with the statistical analyses. We are also grateful to EEA INTA Esquel, Héctor Jones, Ronaldo Jones, Julio Sale Rodríguez and Alejandro Garzonio for permission to access to sampling sites, and L. Sosa Pfatschbacher and A. H. Maranghello for helpful comments on the manuscript and their invaluable help and support during the realization of this study.

\section{Conflict of interest}

The author declares that there is no conflict of interest.

\section{References}

1. Hudson LW, Newbold T, Contu S, et al. The PREDICTS database: a global database of how local terrestrial biodiversity responds to human impacts. Ecology and Evolution. 2014;4(24):4701-4735.

2. Lencinas MV, Martinez Pastur G, Gallo E. Mitigation of biodiversity loss in Nothofagus pumilio managed forests of South Patagonia. Understanding biodiversity loss: an overview of forest fragmentation in South America. Part III: Landscape ecology for conservation, management and restoration; 2008. p. 112-120.

3. Deferrari G, Camilion C, Martínez-Pastur G, et al. Changes in Nothofagus pumilio forest biodiversity during the forest managemant cycle: Birds. Biodiversity and Conservation. 2001;10(12):2093-2108.

4. Rovere AE, Blackhall M, Cavallero L. Conservación y Restauración En: Raffaele E, de Torres Curth M, editors. Ecología e Historia Natural de la Patagonia Andina: un cuarto de siglo de investigación en biogeografía, ecología y conservación. Ciudad Autónoma de Buenos Aires, Fundación de Historia Natural Félix de Azara; 2014. p 183-203.

5. Reader RJ, Bricker BD. Response of five deciduous forest herbs to partial canopy removal and patch size. Am Midl Nat. 1992;127:149-157.

6. Lewis CN, Whitfield JB. Braconid wasp (Hymenoptera: Braconidae) diversity in forest plots under different silvicultural methods. Environmental Entomology. 1999;28(6):986-997.

7. Picket STA, White PS. The ecology of natural disturbance of natural patch dynamics. Academic Press; 1985. 472 p.

8. Pimm SL. The Balance of Nature? Ecological Issues in the Conservation of Species and Communities. University of Chicago Press, Chicago, Illinois; 1991.

9. Raffaele E, de Torres Curth M, Morales CL, et al. editors. Ecologia e Historia Natural de la Patagonia Andina. Un cuarto de siglo de investigación en biogeografia, ecologia y conservación. Fundacion de Historia Natural; 2014. 255 p.

10. Farji-Brener AG, Corley JC, Bettinelli J. The effects of fire on ant communities in northwestern Patagonia: the importance of habitat structure and regional context. Diverstiy and Distributions. 2002;8(4):235-243.

11. Wilson EO. The little things that run the world (the importance and convservation of invertebrates). Conservation Biology. 1987;1(4):334-346.

12. Izhaki I, Levey DJ, Silva WR. Effects of prescribed fire on an ant community in Florida pine savanna. Ecological Entomology. $2003 ; 28(4): 439-448$

13. Orgeas J, Beattie AJ. Designing a cost-effective invertebrate survey: a test of methods for rapid assessment of biodiversity. Ecological Applications. 1996;6(2):594-607.

14. Niemelä J. Carabid beetles (Coleoptera: Carabidae) and habitat fragmentation: a review. Europe Journal of Entomologist, 2001;98:127-132.

15. Sackmann P, Farji-Brener A. Effect of fire on ground beetles and ant assemblages along an environmental gradient in NW Patagonia: Does habitat type matter?. Ecoscience. 2006;13(3):360-371.

16. Sasal Y, Raffaele E, Farji-Brener A. Succession of ground - dwelling beetle assemblages after fire in three habitat types in the Andean forest of NW Patagonia, Argentina. Journal of Insect Science. 2010;10:1-17.

17. Kim K. Biodiversity, conservation and inventory: why insects matter. Biodiversity and Conservation. 1993;2(3):191-214.

18. Southwood T. Ecological Methods: Whit particular reference to the study of insect populations. 2nd Ed. Cambridge, University Press. Cambridge, England; 1989.524 p.

19. News T. Invertebrate Surveys for Conservations. 1st Ed. Oxford, University Press. Oxford, England; 1998. 240 p.

20. Ross H. Introducción a la entomología general y aplicada. Ed Omega, Barcelona (España); 1973. 536 p.

21. Richards OW, Davies RG. Tratado de entomologia Imms. Volumen 2: Clasificacion y Biologia. Ed. Omega, Barcelona, España. 1984. 998 p.

22. Morrone JJ, Coscarón S, editors. Biodiversidad de Artrópodos Argentinos: una perspectiva biotaxonómica. Ediciones Sur, La Plata, Argentina; 1998.599 p.

23. Romoser WS, Stoffolano JG. The science of entomology. WCB/McGrawHill (EEUU); 1998. 605 p.

24. Marvaldi AE, Lanteri AA. Key to higher taxa of South American weevils based on adults characters (Coleoptera: Curculionidae). Revista Chilena de Historia Natural. 2005;78(1):65-87.

25. Claps LE, Debandi G, Roig-Juñent S, editors. Biodiversidad de Artrópodos Argentinos. Sociedad Entomológica Argentina; 2008.

26. Braun-Blanquet J. Plan sociology, the study of plant communities, traducción del alemán, revision y edición. de Fuller GD, Conrad HS, editors. reimpreso por Hafner Pub Co, Nueva York; 1932. 439 p.

27. Mueller-Dombois D, Ellenberg H. Aims and methods of vegetation ecology. New York, NY: John Wiley and Sons, Inc; 1974. 547 p. 
28. Dimitri M, Orfila E. Tratado de Morfología y Sistemática Vegetal. Ed. ACME, SACI; 1985.

29. Zuloaga FO, Morrone O, Belgrano MJ, editors. Catálogo de plantas vasculares del Cono Sur (Argentina, sur de Brasil, Chile, Paraguay and Uruguay). Volumenes I, II and III. Monographs in Sistematic Botany from the Missouri Botanical Garden; 2008;107:1-983.

30. Sokal RR, Rohlf FJ. Biometry: The principles and Practice of Statistics in Biological Research, 3rd ed. Freeman and Company; 1995.

31. Gotelli NJ, Colwell RK. Quantifying biodiversity: Procedures and pitfalls in the measurement and comparison of species richness. Ecology Letters. 2001;4:379-391.

32. Clarke KR, Green RH. Statistical design and analysis for a biological effects study. Marine Ecology Program Service. 1988;46:213-226.

33. Kruskal JB, Wish M. Multidimensional Scaling. Sage Publications. Beverly Hills, California; 1978.

34. Hammer O, Harper DAT, Ryan PD. PAST: Paleontological statiscs sofwre package for education and data analysis. Paleontologia Electronica. 2001;4:1-9.

35. Di Rienzo JA; Casanoves F, Balzarini MG. InfoStat versión 2014. Grupo InfoStat, FCA, Universidad Nacional de Córdoba, Argentina; 2014.

36. Bess EC, Parmenter RR, McCoy S, et al. Responses of a riparian forestfloor arthropod community to wildfire in the middle Rio Grande valley, New Mecixo. Environmental Entomology. 2002;31(5):774-784.
37. Niemelä J, Spence JR. Distribution of forest dwelling carabids (Coleoptera): spatial scale and the concept of communities. Ecography. 1994;17(2):166-175.

38. Niwa CG, Peck RW. Influence of prescribed fire on carabid beetle (Carabidae) and spider (Araneae) assemblages in forest litter in southwestern Oregon. Environmental Entomology. 2002;31(2):785-796.

39. Niemelä J, Langor D, Spence JR. Effects of clear cut harvesting on boreal ground beetle assemblages (Coleoptera: Carabidae) in western Canada. Conservation Biology. 1993;7(3):551-561.

40. Spagarino C, Martínez Pastur G, Peri P. Changes in Nothofagus pumilio forest biodiverstiy during the forest management cycle. Insects Biodiverstiy Conservation, 2001;10(12):2077-2092.

41. Niemelä J, Spence JR, Cárcamo H. Establishment and interactions of carabid populations: an experiment with native and introduced species. Ecography. 1997;20(6):643-652.

42. Ruggiero A, Farji-Brener A, Kun M. Beetle abundance-environment relationships at a Subantartic-Patagonian transition zone. Insect Conservation and Diversity. 2009;2(2):81-92.

43. Kitzberger T, Steinaker DF, Veblen TT. Effects of climatic variability on facilitation of tree establishment in northern Patagonia. Ecology. 2000;81(7):1914-1924.

44. Mazía N, Chaneton E, Kitzberger T. Small-scale habitat use and assemblage structure of ground-dwelling beetles in a Patagonian shrub steppe. Journal of Arid Environments. 2006;67(2):177-194. 